\title{
A Conception of Establishing Human Life Information Database
}

\author{
Lei Ma* \\ The Center for the Philosophy of Problem, Huaqiao University, China
}

Submission: January 30, 2019; Published: February 08, 2019

*Corresponding author: Lei Ma, The Center for the Philosophy of Problem, Huaqiao University, Xiamen, China

\section{Opinion}

Over 100 billion people are said to have lived on our planet, but little information about their lives remains. Most people's physique, thoughts, kinship, friendship, and life trajectory are lost in the Loess with the passage of time. Anthropologists and historians can only search for traces of our ancestors in deep graves and remnants of written symbols. The written history in this way is incomplete, out of context, full of speculation and imagination. At present, there are about 7 billion people living on earth. They are the descendants of more than 100 billion people. As far as individuals are concerned, there are few basic life information that can be recalled more than three generations, let alone a long family lineage. The so-called "genealogy" that remains at present is basically a string of abstract names and symbols. Where is the rich life information of those vivid lives? Although historical celebrities are lucky to leave some of their life information, more and more deductions confuse their reallife stories with infinite conjectures and become the talks of future generations.

Different from animals, mankind built a civilization and culture of its own. They are eager to pursue the memory of their ancestors, to record and treasure their true stories, and to inherit the accumulated culture from generation to generation. The current civilization, however, is basically holistic and semiobscure. We cannot clearly trace the individual's blood link and historical changes. The interlocking dynamic life network is torn into fragments and formed the so-called "human history" through romantic or utilitarian transformation.

In the past, only God knows. Today, having entered the era of high technology and the Internet, we can record and preserve what is happening, so that our future generations can clearly trace the information of each individual life that has appeared. From now on, we should start the human life information project and establish the human life information database as soon as possible. Who is my grandpa's grandpa? Who is my grandmother's grandmother? What are my grandparents 'relatives and friends like? If our descendants want to know, they can enter their private network space through a family password or friendship password in this system and watch the rich life information they record and store personally. Their birth, growth, health, work, life, thoughts and so on can be reproduced through text, audio or video.

In this system, everyone has their own cyberspace, which can be accessed by password into the private space of her father, mother, wife, son, daughter, friends, colleagues, classmates and students. By the owner of the space, the information of each space is stored and managed, and the decision to lock and unlock is made. Others cannot enter the spaces and have no right to add or modify other people's information without authorization. From this, a huge network of human life information is formed. Horizontally, if each lock is open, individuals can find anyone on the earth through spaces to achieve real-time communication; vertically, if all the kinship locks are opened, the origins and backgrounds of everyone's blood relationship will be clear. Family genealogy sorted out by the system itself allows us to put our lingering yearning into a permanent memorial space, to pray for generations of ancestors and to express our joy, anger and sorrow. Our future generations no longer must face the storm and spend the time to sweep the graves in the real cemetery. The space of the cemetery is limited and the network space is infinite. What's more, the network is more real, richer and longer than the cemetery. Looking ahead, once the life information system is integrated with the virtual intelligent robot system, our descendants can visit and interact with any ancestor in the virtual space. What kind of excitement it will be!

Respect and cherish every life, leave a clear memory for history! This is a new awakening and enlightenment of mankind! Remembering every detail of history can help us and our descendants adjust our moral situation in real time and promote the evolution of human morality. Who wants to have an evil ancestor? Who wants their offspring to inherit an evil spirit? In order to leave a good impression on our children and grandchildren for thousands of generations and set a good example, we will naturally urge ourselves to be less evil and more kind in our hearts. Naturally, we will leave a good record of the 
life and thought in our own space, dedicate our beliefs to them as the best gift, bless them, and family culture closely related to human civilization will also be presented and inherited in specific historical details. If human genome engineering helps us to solve the problem of blood relationship between people in the biological sense, human life information engineering will show the meaning and value of individual life in the sociological sense with rich life content. Love, justice, freedom and equality, these beautiful ideas will go deep into the hearts of our future generations through the stories recorded by each fresh life and play a role for a long time.

\section{Notes on the Contributor:}

Lei Ma, a Chair in the Center for the Philosophy of Problem at Huaqiao University. He was a Visiting Scholar at the Department of Philosophy at the University of Michigan in 2009. His cooperative professor is Lawrence Sklar, whose book Theory and Truth was translated by him into Chinese and published by the Science Press in 2014. Before coming to Huaqiao University, he was a Professor at Southeast University. His doctoral degree is from Wuhan University. His areas of competence are the philosophy of science, the philosophy of problem, logic and sociology.

\section{Acknowledgement}

This research was supported by Chinses Social Sciences Fund (17BZX004)

\section{Your next submission with Juniper Publishers will reach you the below assets}

- Quality Editorial service

- Swift Peer Review

- Reprints availability

- E-prints Service

- Manuscript Podcast for convenient understanding

- Global attainment for your research

- Manuscript accessibility in different formats

( Pdf, E-pub, Full Text, Audio)

- Unceasing customer service

Track the below URL for one-step submission https://juniperpublishers.com/online-submission.php 